\title{
METHODS FOR ESTIMATION OF MARKET POWER IN ELECTRIC POWER INDUSTRY
}

\author{
M. Turcik, I. Oleinikova, \\ G. Junghans, M. Kolcun \\ Laboratory for Power System Mathematical Modelling, \\ Institute of Physical Energetics, \\ Aizkraukles iela 21, Riga, LV-1006, LATVIA
}

The article is related to a topical issue of the newly-arisen market power phenomenon in the electric power industry. The authors point out to the importance of effective instruments and methods for credible estimation of the market power on liberalized electricity market as well as the forms and consequences of market power abuse. The fundamental principles and methods of the market power estimation are given along with the most common relevant indicators. Furthermore, in the work a proposal for determination of the relevant market place taking into account the specific features of power system and a theoretical example of estimating the residual supply index (RSI) in the electricity market are given.

Key words: market power, electricity market, liberalization, regulation.

\section{INTRODUCTION}

The phenomenon of market power and its impact on the market operation have arisen with introduction of liberalization and efforts to take advantages of competitive environment. The electric power industry or, in a wider meaning, the energy sector has several specific features which can cause fast (and often unexpected) abuse of market power, with considerable negative consequences to the entire market. After unbundling the electric power industry the estimation of market power should be maintained in the sectors where liberalization has already been introduced [1]. Owing to logical inefficiencies some activities remain still controlled - ergo under regulation (see Fig. 1).

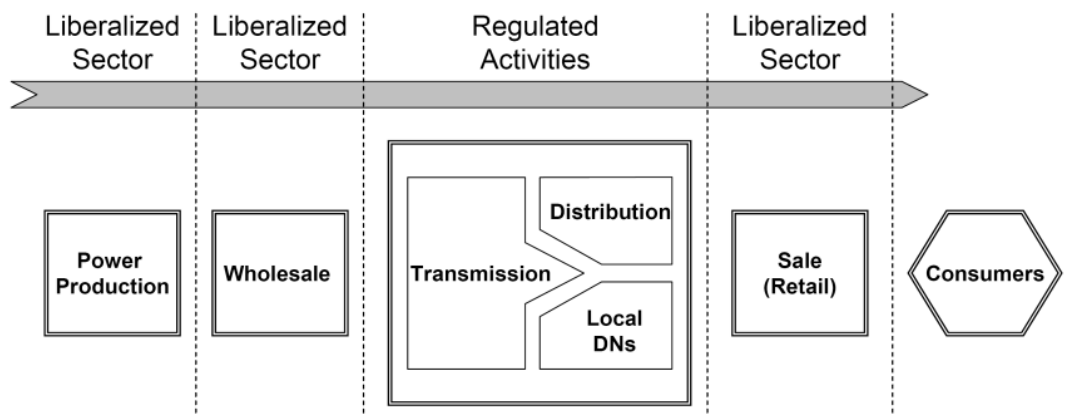

Fig. 1. The structure of unbundled electric power industry. 
The expected positive outcomes from the introduction and growth of competition in the electric power industry could be summarized as follows.

- Increase in the efficiency of companies involved into competition in the use of resources and creation of pressure for investments into advanced technologies.

- Increase in the competition that would reduce the price-cost markups of competitors.

- Creation of the conditions with higher potential for maximizing the social welfare as compared to monopolistic conditions (see Ch. 2.1).

\section{INCENTIVES FOR MARKET POWER ESTIMATION}

Having arisen in the general economics, the term market power is assumed as a company's ability to manipulate the prices by influencing supply, demand or both. However, in order to hit immediate target on a market such as profit maximizing, the definition of a company's market power may be abridged as the ability to raise the market price of product above the marginal costs of production or, in other words, the ability of a company to maximize the profit margin on the market without losing the market share. The situation can be expressed via the commonly used Lerner's index as [2]

$$
L_{i}=\frac{C_{m}-M C}{C_{m}},
$$

where $C_{m} \quad$ is the market price set by the company, and

$M C$ is the company's marginal cost,

that is:

No market power $\leftarrow 0 \leq L_{I} \leq 1 \rightarrow$ Absolute market power

The economics theory and practice suggest that the price on short-term competitive electricity markets is set by the short-run marginal cost (SRMC) of the last unit of which it is required to meet the demand. Thus, when the price above the SRMC is observed this can be an indicator of the market that is less than perfectly competitive.

However, the market power - according to the strategic behaviour of players - is NOT necessarily characterized by direct efforts to maximize the profit margin. Abusing of market power can take place also when the companies which are fighting for dominance in the competitive market focus on the market share and not on the profit in the early period when they are building their businesses. Such companies will temporarily accept negative profit margins while they gain the market share and dominance over other competitors.

Due to these reasons, the difference between "potential" and "in force" market power has to be emphasized. Since the aforementioned Lerner index ascertains the market power "in force", the indices that estimate market structure (market concentration) such as HHI, CR, PSI or RSI show "potential" market power which could be - but not necessarily is or will be - abused. 


\subsection{Impact of market power abuse on consumers' surplus}

According to the theory of economics, the consumers' surplus illustrates how people can gain from buying a commodity or a service (electricity), but it does not mean that in this situation suppliers (producers) have to lose, as the marketplace is not a „zero sum game”. Surplus of consumers and producers can rise at the same time from the trade by specialization and exchanges that add to the general prosperity (to the social welfare) [3].

Adverse situation occurs when the competitor (a monopoly) has and consequently abuses the market power, thus changing conditions on a market in the way of maximizing the own profit. The social loss in this case is seen in Fig. 2.

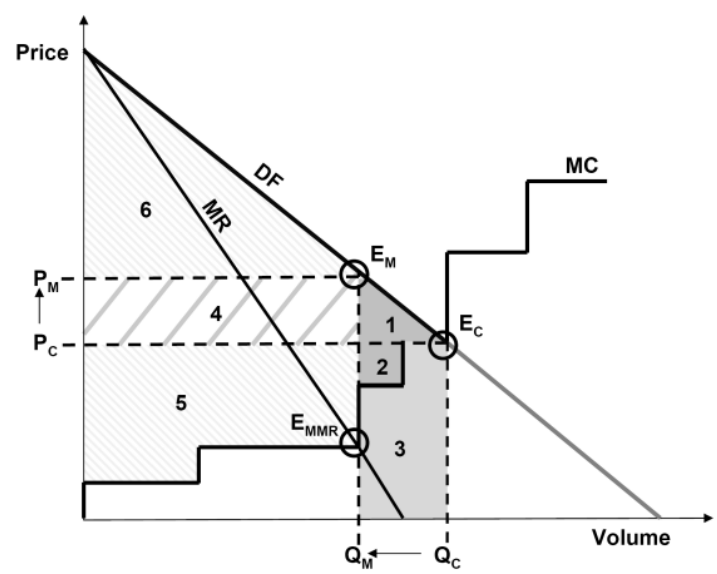

Fig. 2. Social loss caused by monopoly.

The total revenue $(T R)$ is given as the product of price which is obtained for a particular volume and this volume; it could be expressed as [3]

$$
T R(Q)=P(Q) \cdot Q \text {. }
$$

The marginal revenue $(M R)$ is determined as the $T R$ change from selling one extra unit (expressed by Eq. (2)):

$$
M R=\frac{d T R}{d Q}=\frac{d P}{d Q} \cdot Q+P
$$

Assume the demand function $(D F)$ and the function of marginal cost $(M C)$ of production according to Fig. 2, with modelling of two cases: the first with perfectly competitive market and the second - as a monopoly on the production side.

In a perfectly competitive market the price of electricity $\left(P_{c}\right)$ is determined by the $M C$ of marginal generator. Producers (generators) do not have any impact on the price, so this price on a market does not change with changes in volume of the producer's energy sold (they are "price takers"); hence, $\frac{d P}{d Q}=0$. Intersection of the supply and demand curves $\left(E_{c}\right)$ determines volume $\left(Q_{c}\right)$ and price $\left(P_{c}\right)$ on the 
perfect competitive market. In Fig. 2, the social welfare as the sum of generators' and consumers' surplus is given as that of areas 1, 2, 4, 5, 6 .

In contrast with the competitive market, the monopoly of a producer allows maximizing his profit by setting the volume of production on the level of his marginal revenue $\left(E_{M M R}\right)$. This monopolistic action, as compared with the perfect competitive environment, causes selling by the monopolist a smaller volume $\left(Q_{M}\right)$ at a higher price $\left(P_{M}\right)$, and thus reduces the overall social welfare by areas 1 and 2 . Therefore, the social welfare in the case of monopoly is shown in Fig. 2 by areas 4 , 5 , 6 . Area 4 presents the profit of monopolist from the surplus which must be paid by consumers. The production of monopoly as a ,price maker" is facing a downward trend of the demand curve, which means that an increase in production should result in a decrease in price; hence, according to Eq. (2) $\frac{d P}{d Q}<0$.

In the process of regulatory reforms in the electric power industry, the mitigation of market power is one of the basic problems the regulators have to deal with. To supervise well-functioning competition on the market, credible methods are needed for measuring and estimating the market power of relevant players.

The methodology and most common indicators for estimation of the market concentration are discussed in the next chapter.

\section{METHODOLOGY FOR MARKET POWER ASSESSMENT}

The market power estimation process has always to contain: geographical determination of relevant market place for a specific product (in our case electricity) and estimation of market power through suitable indicators (HHI, CR, PSI, RSI or $L_{i}$, see below).

\subsection{Determination of relevant market place}

The first step in a competition analysis is geographical determination of the market place for a specific product $[4,5]$. Determination of the product (in our case electricity as homogenous commodity) is a relatively simple task. The geographical determination of market is much trickier. Position of territory A with respect to other territories $(\mathrm{B}, \mathrm{C}, \mathrm{D})$ in the market place determination process is exemplified in Fig. 3.

The decision about the geographical market place in the case of interconnected power systems should be made in compliance with particular conditions based on the correlation of prices and the transmission capabilities (commercial transfer capacity - NTC) between the territories. These conditions are formulated as follows.

1. Sufficient capacity of interconnectors, equal prices $\Rightarrow$ existence of common market between the assumed territories.

2. Sufficient capacity of interconnectors, different prices $\Rightarrow$ functioning of market can be hampered by the internal transmission capability of power transmission systems inside the territory(ies).

3. Insufficient capacity of interconnectors, equal prices $=>$ possible reasons could be: coincidence of supply and demand curves in the countries; 
collusion of power producers in a territory with lower production costs in order to set the offer at a level of foreign territories with higher production costs.

4. Insufficient capacity of interconnectors, different prices $=>$ non-existence of common market between the territories. applied.

To find a market's boundaries, the SSNIP test or Granger's test are generally

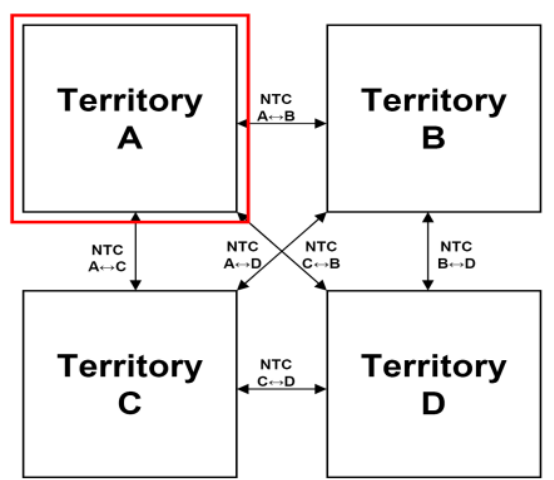

Fig. 3. Determination of the relevant market place.

\subsection{Market concentration indices}

After the relevant market place is found, the most common indices for estimation of market concentration and thus of market power are to be determined.

\section{Herfindahl-Hirschman Index (HHI)}

This index is a simple sum of the squares of Companies' market shares. Generally, higher HHI means position that is closer to the monopoly conditions. Lower market concentration (HHI) leads to higher competition. The index is determined as

$$
\mathrm{HHI}=F_{1}^{2}+F_{2}^{2}+F_{3}^{2}+F_{4}^{2} \ldots F_{n}^{2},
$$

where $F_{n}$ is the share of Company , $n$ " in per cent, that is:

$$
\text { Perfect competition } \leftarrow 0<\mathrm{HHI} \leq 10000 \rightarrow \text { Monopoly }
$$

In [5] the following HHI values are given:

- HHI less than 1500 (a competitive marketplace);

- HHI 1500-2500 (a moderately concentrated marketplace);

- HHI 2500 or greater (a highly concentrated marketplace).

The European Commission considers a marketplace with HHI $<1000$ as competitive, without specific requirements on the merger control [6].

Exponentiation of the market shares ensures that the method with HHI is sensitive to the largest companies' market shares and less sensitive to those of smaller companies. The relevant calculations could be performed based on the installed capacity (ex-ante \& ex-post analyses) or the generated electricity (ex-post analysis). 


\section{Concentration Ratio (CR)}

The concentration ratio is used for measuring the total output of , $n^{\text {" largest }}$ companies on the market $\left(\mathrm{CR}_{n}\right)$. The most common is application of $\mathrm{CR}_{4}$ or $\mathrm{CR}_{8}$, which means the sum of the shares of 4 or 8 largest companies, respectively. For this ratio we have:

$$
\begin{aligned}
& \mathrm{CR}_{n}=\sum_{i=1}^{n} S_{i}=S_{1}+S_{2}+S_{3} \ldots S_{n}, \\
& 0<\mathrm{CR}_{n} \leq 100 \% .
\end{aligned}
$$

In [7] the following market characteristics involving $\mathrm{CR}_{\mathrm{n}}$ are considered:

- $0 \%$ : perfect competition.

- $100 \%$ : total concentration $=>$ monopoly if $\mathrm{CR}_{1}$; high oligopoly if $\mathrm{CR}_{4}$ or $\mathrm{CR}_{8}$.

- $0-50 \%$ : the range from perfect competition to oligopoly.

- 80-100\%: the range from oligopoly to monopoly.

\section{Pivotal Supplier Index (PSI)}

This is a binary index assuming the value, 0 " or "1" and indicating the pivotality of examined supplier $C_{x}$ [8]. When supplier $C_{x}$ is needed to satisfy the demand in a particular situation (i.e. this supplier is pivotal), then PSI $=1$. In the case supplier $C_{x}$ is not needed for this purpose in a particular situation (supplier $C_{x}$ is non-pivotal), then PSI $=0$. The pivotalness shows the market power of particular supplier $C_{x}$, i.e.:

$$
\mathrm{PSI}=1 \cdot[\overbrace{C_{x}>\sum_{i=1}^{n} C_{i}-\text { Total demand }}^{A_{X}}] \text {, }
$$

where $C_{x}$ is the capacity of the largest supplier or of the supplier under consideration;

$\sum_{i=1}^{n} C_{i}$ is the capacity of all suppliers including $C_{x}$;

Total demand is defined as the total market demand in the situation considered.

The corresponding assumptions are:

$$
\text { if } A_{x} \text { is TRUE } \Rightarrow A_{x}=1 \text {; if } A_{x} \text { is FALSE } \Rightarrow A_{x}=0 \text {. }
$$

The most significant drawback when using PSI is the binary identification itself. In situations close to the threshold there is no alert as to possible threats to the market power.

\section{Residual Supply Index (RSI)}

The Residual Supply Index (RSI) has been formulated specifically for the market power estimation in the electric power industry. Similar to PSI, this index 
estimates the pivotality of supplier $C_{x}$. However, unlike PSI with only binary identification, RSI points to position of pivotal supplier $C_{x}$ in a particular situation (see Fig. 4) [9].

This latter index shows the residual supply to demand ratio calculated by the following equation as

$$
\mathrm{RSI}=\frac{\sum_{i=1}^{n} C_{i}-C_{x}}{\text { Total demand }},
$$

where $\sum_{i=1}^{n} C_{i}$ is the capacity of all suppliers including $C_{x}$ plus the total net import;

$C_{x}$ is the capacity of the largest supplier or of the examined supplier (which in a power market might be different for every hour) reduced by the (pro)portion already contracted to a particular load;

Total demand of the system is determined as a metered load including purchased ancillary services.

Generally, the lower is RSI of the analyzed market with examined supplier $C_{x}$ the higher is the market power of this supplier (see Fig. 4).

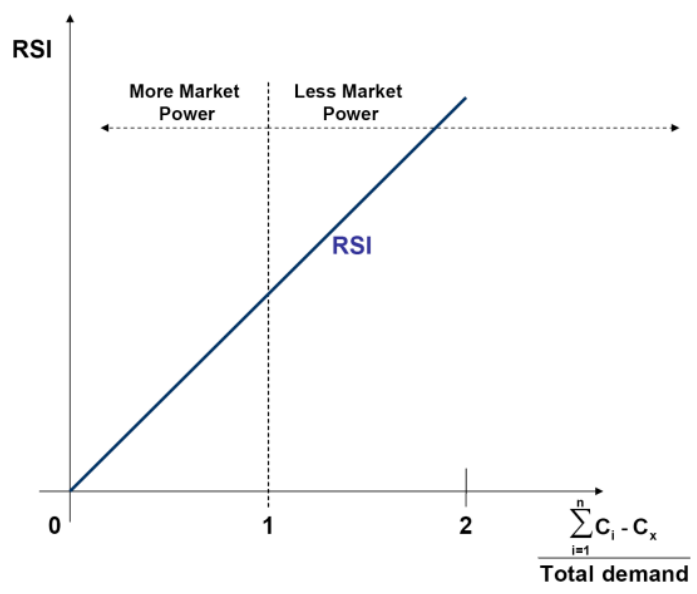

Fig. 4. Market power estimation via RSI.

\section{RSI ESTIMATION ON THE ELECTRICITY MARKET}

To exemplify the RSI estimation on the electricity market, Fig. 5 shows the total annual load of three Baltic States (EE, LV, LT) in 2010 and the national available supply as well as the structure of suppliers in the region. The example serves as an illustration rather than description of the real situation in the Baltic.

According to the modelled situation, the competitors of a major supplier are not able during the entire year to cover the total demand of a system; hence, opportunity to abuse the market power by the major supplier arises in the periods when the demand cannot be covered by residual available power supply (depicted in Fig. 5 by dashed squares). 


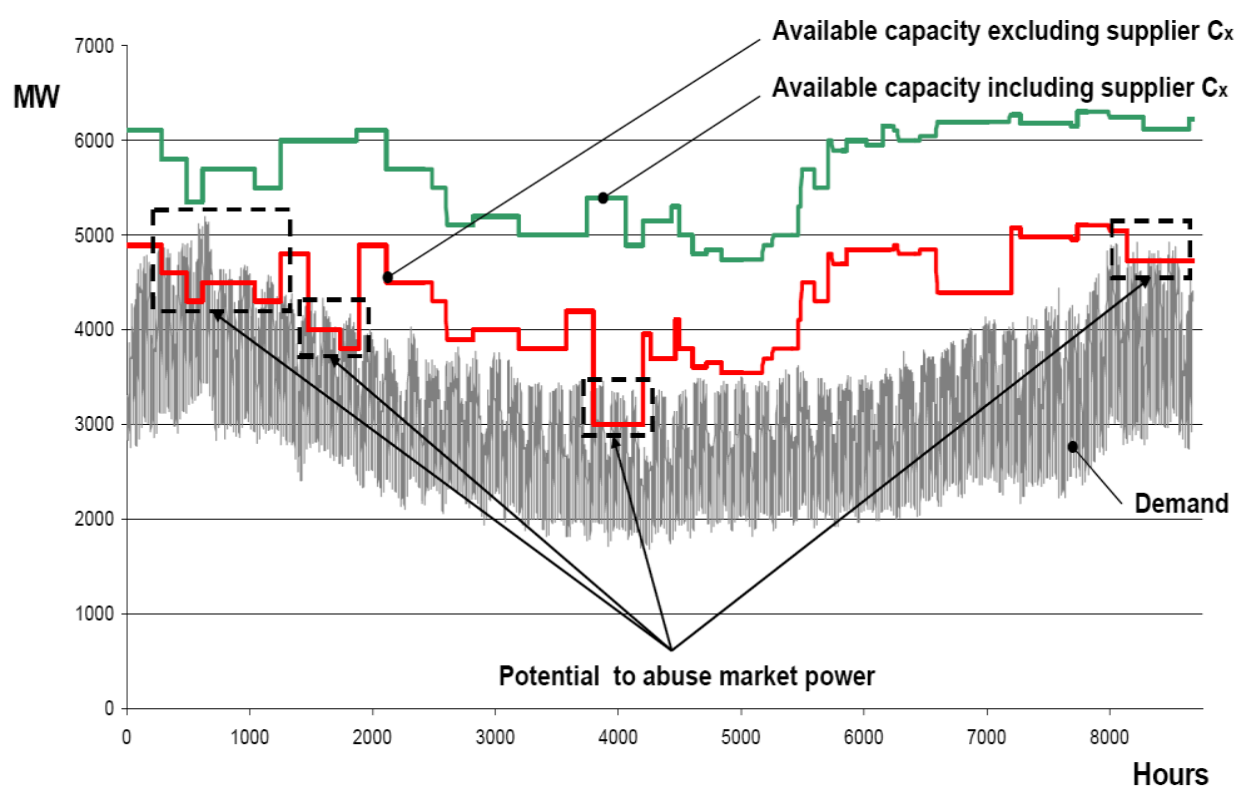

Fig. 5. Example of RSI estimation.

In practical RSI estimations related to the electricity market (performed taking the demand on the hourly basis) the values of available supply can be assumed as weekly averaged (including planned outages). In order to obtain a descriptive RSI value on a particular market for the entire year, the hourly acquired values of this index are averaged.

As achievements of the RSI analysis we can consider the percentage obtained for the year when the major supplier is pivotal as well as the maximum and minimum load covered by the remained supply during the year.

According to the example given in Fig. 5, minimization of the need for $C_{x}$ and its duration is the key target for a competitive electricity market. This target could be achieved through changes in the supply structures - e.g. by involving new competitors or by dividing the existing.

\section{CONCLUSIONS}

Considering the time scales of trading on electricity markets, assessment of the market power in electric power industry should be performed on the hourly basis. This could be done with a relatively high precision in the ex-post analysis, while in the ex-ante analysis - due to uncertainties and unavailability of the input data - it is much more complicated. The important part of the market power analysis consists in identifying the state of share(s) and interdigitations of the ownership between suppliers on the market place under estimation.

All of the discussed market power indicators - whether they identify "potential" or "in force" market power - require a different approach to the identification and estimation criteria; hence, application of all indicators to every particular situation under assessment could considerably raise the credibility of results. 
Abusing the market power by competitive players can considerably deform the market environment and hamper achieving the main targets/benefits of liberalization establishment (see [1, 10]); therefore, strong authority(ies) with the appropriate instruments and methods for estimation of competitive functionality of market environment are essential and must work with high precision. Furthermore, the results of such estimation have impact on the overall power system design not only legislative but also physical; thus, these results should be reasonably taken into account in the planning and development processes.

The theoretical background provided and the methodology proposed in the article for estimation of the market power in specific environment of the liberalized electricity market will be used for further research based on application of real data sets.

\section{ACKNOWLEDGEMENTS}

The paper is supported by the ESF Project "Scientific Group Supporting Latvian Activities of the European Strategic Energy Technology Plan", No.1DP/1.1.1.2.0/09/A-PIA/VIAA/027 and by project VEGA SR No. 1/0414/12.

\section{REFERENCES}

1. Hunt, S. (2002). Making Competition Work in Electricity ( $1^{\text {st }}$ ed-n). New York: John Wiley \& Sons, ISBN-10: 0471220981, pp. 464.

2. Feinberg, R.M. (1980). The Lerner Index, concentration, and the measurement of market power. Southern Economic Journal, 46 (4), 1180-1186.

3. Froeb, L.M., Mccann, (2009). Managerial Economics: A Problem Solving Approach ( $2^{\text {nd }}$ ed-n). South-Western, Cengage Learning, ISBN-10: 1-439-07798-3, pp. 345.

4. Juselius, M., \& Stenbacka, R. (2008). The Relevant Market for Production and Wholesale of Electricity in the Nordic Countries: An Econometric Study. Discussion Paper No. 222, Helsinki: University of Helsinki and HECER

5. U.S. Department of Justice and Federal Trade Commission (2010). Horizontal Merger Guidelines. http://www.justice.gov/atr/public/guidelines/hmg2010.pdf.

6. European Commission (2010). EU Competition Law: Rules Applicable to Merger Control. http://ec.europa.eu/competition/mergers/legislation/merger_c-ompilation.pdf.

7. CONCENTRATION RATIO, AmosWEB Encyclonomic WEB*pedia, http://www.AmosWEB.com, AmosWEB LLC, 2000-2012. (Accessed: February 5, 2012).

8. Twomey, P., Green, R., Neuhof, K., \& Newbery, D. (2005). A Review of the Monitoring of Market Power: The Possible Roles of Transmission System Operators in Monitoring for Market Power Issues in Congested Transmission Systems. MIT-Center For Energy and Environmental Policy Research.

http://web.mit.edu/ceepr/www/publications/reprints/Reprint_209_WC.pdf.

9. Shefrin, A. (2002). Predicting Market Power Using the Residual Supply Index. Presented to FERC Market Monitoring Workshop, Dec. 3-4

10. Blumsack, S., \& Lave, L. B. Mitigating Market Power in Deregulated Electricity Markets. Carnegie Mellon University. http://www.personal.psu.ed-/sab51/usaee.pdf. 


\title{
TIRGUS SPĒJAS ANALĪZE UN NOVĒRTĒĚSANA ENERĢĒTIKAS NOZARE
}

\author{
M. Turcik, I. Oḷeiniikova, G. Junghāns, M. Kolcun
}

Kopsavilkums

Rakstā galvenā uzmanība veltīta elektroenerǵijas tirgus spējai un tās noteicošo faktoru analīzei. Tirgus spēja tiek definēta kā uzņēmuma spēja palielināt produkta cenu tirgū virs robežizmaksām ražošanas posmā, citiem vārdiem sakot, tā ir uzņēmuma spēja palielināt tirgus peļnu, tai pat laikā nezaudējot dạ̧u tirgus.

Paredzamie pozitīvie rezultāti, kurus nodrošinās liberalizēta elektroenerǵijas tirgus ieviešana un konkurences palielināšanās elektroenerğijas ražošanas nozarē, ir sekojoši:

- tirgū iesaistīto uzņēmumu konkurences efektivitātes palielināšanās resursu izmantošanā, kas ietekmē investīcijas augsto tehnologíju jomā;

- konkurences palielināšanās, cenu un izmaksu uzcenojumu samazināšanās konkurentu starpā;

- tādu nosacìjumu radīšana, kas, salīdzinot ar monopola apstākḷiem, palielina sociālās labklājības līmeni.

Saskaņā ar ekonomikas teoriju, patērētāju pārpalikums parāda, kā cilvēki var gūt labumu, iegādājoties preci vai pakalpojumu (elektrība), bet tas nenozīmē, ka šajā situācijā piegādātājam (ražotājam) ir jācieš zaudējumi, jo tirgus nav "nulles summas spēle". Tai pat laikā specializētās tirdzniecības un apmaiņas rezultātā patērētāju un ražotāju pārpalikums var arī pieaugt, kas savukārt var paaugstināt vispārējās labklājības līmeni (paaugstināt sociālas labklājības līmeni). Nevēlama situācija rodas tādā gadījumā, ja tirgus konkurents vēlas l̦aunprātīgi mainīt tirgus nosacījumus par labu sev, maksimāli palielinot tikai savu peļnu.

N̦emot vērā iepriekš minēto, tirgus struktūras (tirgus koncentrācijas) novērtēšanai izmanto sekojošus indeksus: HHI, CR, PSI vai RSI, kas savukārt parāda potenciālo tirgus varu, kura varētu būt vai arī tiks ḷaunprātīgi izmantota. Lai noteiktu kādi tirgus spējas vērtēšanas kritēriji izmantojami, ir jāpiemēro visi rādītāji atkarībā no konkrētas situācijas; tas ievērojami palielinās rezultātu ticamību. Rakstā piedāvāts RSI novērtēšanas piemērs Baltijas valstīs.

14.02.2012. 